\title{
Utikuma Region Study Area (URSA) - Part 2: Aspen Harvest and Recovery Study
}

\author{
by Richard Petrone ${ }^{1, *}$, Kevin J. Devito² and Carl Mendoza ${ }^{3}$
}

\begin{abstract}
The Hydrology Ecology And Disturbance (HEAD-1 and HEAD-2) research programs in the Western Boreal Plains of North-Central Alberta, has provided objective delineation and determination of landscape units characterized by geology and climate. From these landscape indices can be developed that provide information on the scale at which forest, wetland, and aquatic systems are linked to their surroundings and the potential response of an area to particular disturbances. In collaboration with industry, government and NGO planners and ecologists this work establishes a hydrologic risk planning process that evaluates the ecological risk and monetary costs of forest harvest on forest succession and water quality and quantity.
\end{abstract}

\section{RÉSUMÉ}

Le programme de recherche sur l'hydrologie, lécologie et les perturbations (HEAD-1 et HEAD-2) dans la région des Plaines boréales de l'Ouest, au centre-nord de l'Alberta, a permis de délimiter et de définir objectivement des éléments du paysage sur la base de leur géologie et de leur climat. À partir de ces éléments, il est possible délaborer des indices de paysage qui nous indiquent le niveau de lien entre la forêt, le milieu humide et les systèmes aquatiques et leur environnement immédiat et sur la façon dont un site pourrait réagir à des perturbations données. L'industrie, le gouvernement, ainsi que les planificateurs et écologistes des ONG disposent ainsi d'un processus commun de planification du risque hydrologique permettant dévaluer le risque écologique et les coûts monétaires de l'exploitation forestière sur la succession forestière et sur la quantité d'eau et sa qualité.

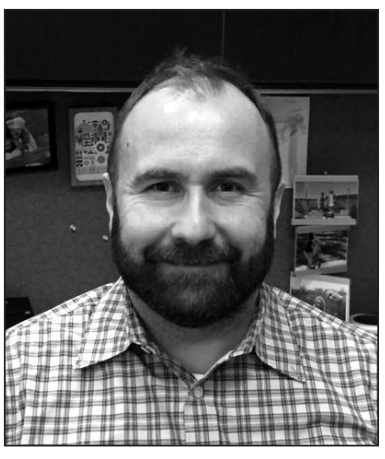

Richard Petrone

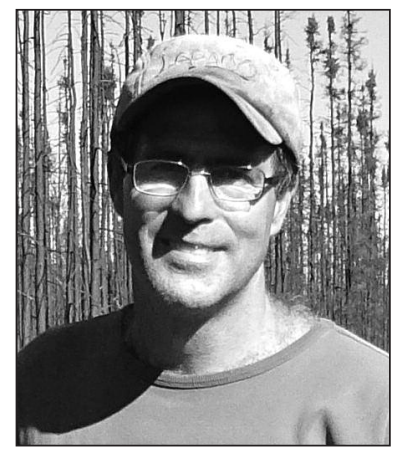

Kevin J. Devito

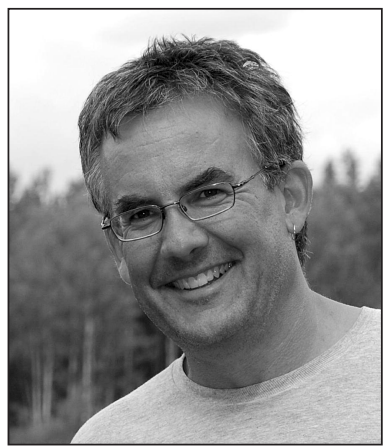

Carl Mendoza reclaimed mine landscapes. Specific deliverables of benefit to the Canadian forestry and oil sands industries arising from the project include the development of:

1) Quantifying the rate of hydrological recovery of regenerating aspen; and

2) Assessing how the water requirements of the regenerating stand are being met, and how this influences the ecohydrological connections with surrounding wetlands.

Given international concern of resource activities in this region, this research addresses national interests in the initial development of appropriate and defensible soil and hydrologic indicators for monitoring and assessing the success of oil sands reclamation and closure plans, and assessing, monitoring and mitigating cumulative impacts of regional land use in the WBF.

\section{Important scientific advancement}

- Initial vegetation succession quickly mitigated impacts of aspen harvested on fine-grained soils (Fig. 1; Table 2; Sutherland et al. 2014, Petrone et al. 2015, Sutherland et al. submitted).

\footnotetext{
${ }^{1}$ Department of Geography and Environmental Management, University of Waterloo, Waterloo, ON * corresponding author: rich.petrone@uwaterloo.ca

${ }^{2}$ Department of Biological Sciences, University of Alberta, Edmonton, AB

${ }^{3}$ Department of Earth and Atmospheric Science, University of Alberta, Edmonton, AB
} 


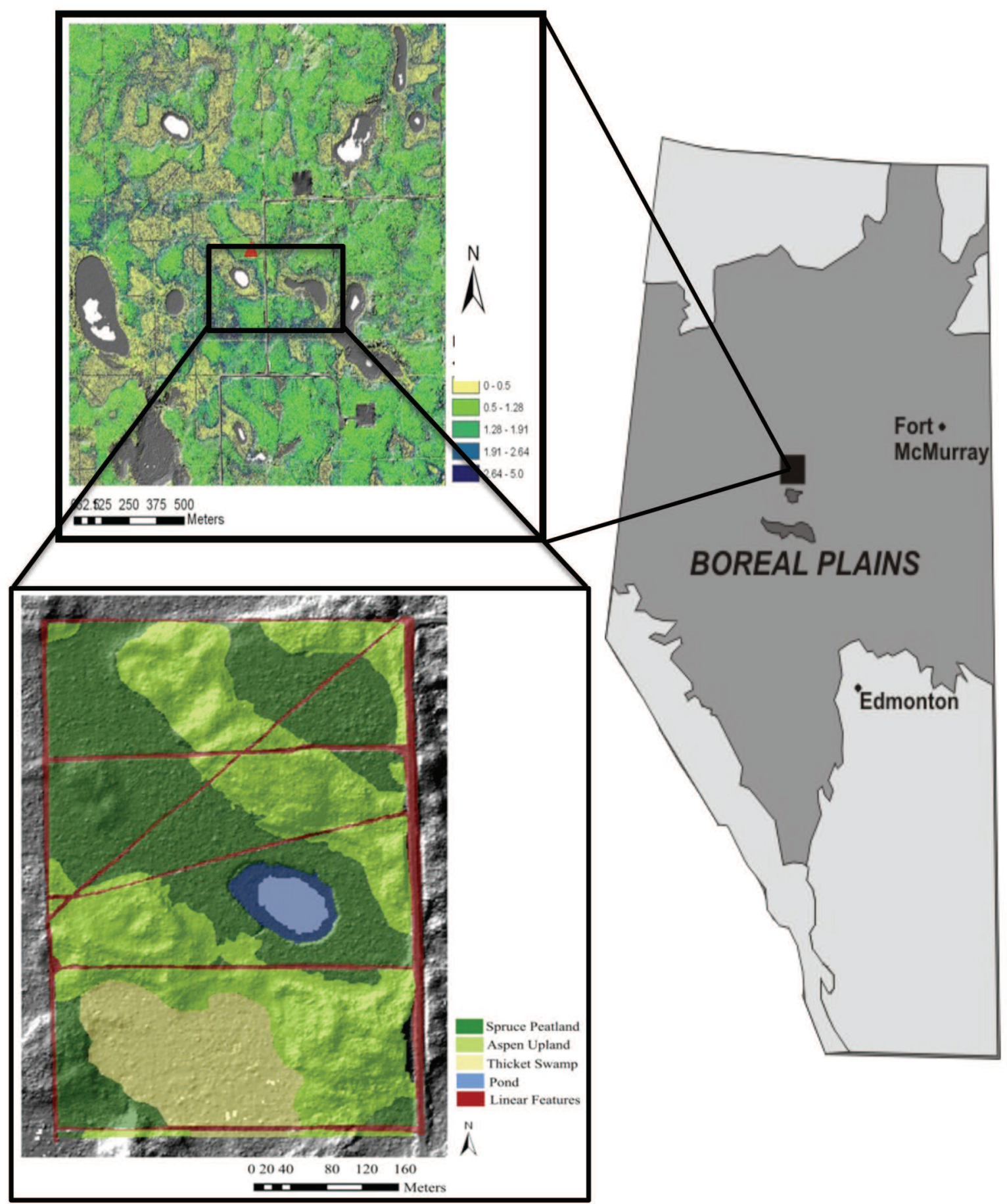

Fig. 1. Map of URSA showing location of detailed catchment ecohydrological studies and location of regional meteorological stations, deep piezometer nests and study lakes.

- Aspen forest lands showed greatly reduced evapotranspiration (ET) and interception (I), with some increase in soil moisture storage after harvesting (Chasmer et al. 2012, Hopkinson et al. 2013, Petrone et al. 2015).

- Soil moisture increases were short-lived due to rapid redevelopment of leaf area as a result of high density regeneration of aspen through root suckering.
- Recovery of transpiration and $I$ to near pre-harvest conditions occurred within three years. As a consequence, no major changes in direction of linkages from wetland to forest lands were observed.

- Overall, there was little difference in low and high streamflow, water chemistry, and vegetation dynamics of adjacent wetlands between catchments with harvested or intact 
aspen forest land (Devito et al. 2012).

- However, where road construction cut deeper to intersect depression and soil storage and was aligned perpendicular to slopes, water was channelled into adjacent wetlands and streams.

- Increased I of slash and evaporation, along with rapid aspen regeneration, compensated for a portion of the reduced ET following harvesting.

- Excess soil moisture was absorbed into surface depressions and deeper soil layers, resulting in increased groundwater recharge with little or no lateral flow to adjacent wetlands and aquatic systems.

- Climate cycles, primarily interannual variation in snow pack, can overwhelm the influence of aspen harvest in the WBP (Table 1; Carrera-Hernandez et al. 2011, Devito et al. 2012).

- During the harvest experiment substantial water table rises were observed in both the uncut and the harvested aspen forest lands (Carrera-Hernandez et al. 2011).

- Measures of root distribution and flow, and soil hydraulic lift show that wetlands can be additional water sources to adjacent forest lands influencing vegetation recovery (Redding and Devito 2010, Brown et al. 2013, Petrone et al. 2015).

- Following harvest, observations of suckering from forest lands (through riparian zones to wetlands) and independent measures of hydrologic lift indicate that rapid regenerative growth of aspen forest lands may tap water resources from adjacent wetlands.

- In contrast, root networks are disconnected in roads and deep cut linear disturbances, which limits additional water sources.

- Rapid regeneration creates conditions of higher water use efficiency (WUE) and returns stand ET to near (70 \%) the pre-harvest rate within three years (Brown et al. 2013, Petrone et al. 2015).

\section{Management/Operational Results}

- In forest management plan (FMP) approvals, the Alberta Government Sustainable Resource Development (SRD) often sets approval conditions that "the revised FMP shall

Location (descriptive)

Table 1. Watershed climatic and physiographic information for the URSA study area

\section{Watershed Location Data}

URSA is located north of Utikuma Lake, north-central Alberta (approximately $400 \mathrm{~km}$ north of Edmonton). The glacial landforms drain into the Wabasca and then the Peace River drainage. The small isolated catchments are located on a moraine, close to the regional topographic high.

Location (geographic)

Biogeoclimatic zone(s)

Watershed area

Elevation range (a.s.1.)

Precipitation (mean annual)

Runoff (mean annual)

Temperature (mean annual) $\quad 1.2^{\circ} \mathrm{C}$ $56^{\circ} 7^{\prime} \mathrm{N}, 115^{\circ} 48^{\prime} \mathrm{W}$ to $55^{\circ} 51^{\prime} \mathrm{N}, 115^{\circ} 6^{\prime} \mathrm{W}$

Boreal Plains, Central mixed-wood, Utikuma uplands

The study watersheds loosely defined by gently sloping forested uplands, which are approximately seven $\mathrm{m}$ above the riparian, wetland and pond areas.

$645-665 \mathrm{~m}$

$483 \mathrm{~mm}$

$67 \mathrm{~mm}$ (range: $4 \mathrm{~mm}$ to $246 \mathrm{~mm}$ )

\begin{tabular}{|c|c|}
\hline Controls & Adjacent catchment - Pond 43 \\
\hline Study duration & 1999 to present \\
\hline Variables measured & $\begin{array}{l}\text { Water and energy balance of reference and experimental (harvested) } \\
\text { study catchments: Above and within the aspen canopy (eddy covari- } \\
\left.\text { ance measurements of water vapour and } \mathrm{CO}_{2}\right) \text {; Energy balance and } \\
\text { Penman-Monteith and Priestley-Taylor estimates of water vapour } \\
\text { fluxes from various land covers (pond, peatland); Interception of pre- } \\
\text { cipitation from canopy, shrub and soil layers; Soil moisture content } \\
\text { and tension; aspen hydraulic lift (isotopes and root excavation); Hill- } \\
\text { slope and stream runoff; groundwater dynamics. } \\
\text { Carbon and nitrogen in soil, water, and vegetation dynamics. } \\
\text { Hydrogeology (deep and shallow piezometer nests), groundwater } \\
\text { geochemical and isotopic ( }{ }^{18} \mathrm{O} \text { and D) characteristics. }\end{array}$ \\
\hline
\end{tabular}

Water and energy balance of reference and experimental (harvested) study catchments: Above and within the aspen canopy (eddy covarifluxes from various land covers (pond, peatland); Interception of preand tension; aspen hydraulic lift (isotopes and root excavation); Hillslope and stream runoff; groundwater dynamics.

Hydrogeology (deep and shallow piezometer nests), groundwate geochemical and isotopic $\left({ }^{18} \mathrm{O}\right.$ and $\left.\mathrm{D}\right)$ characteristics.
Research Design

Catchment budgets and process hydro-meteorological studies

Reference, pre-disturbance data was collected from both Ponds 40 and 43 from 1999 to 2006. The south-facing slope of Pond 40 was harvested in the winter of 2007 , followed by the north-facing slope in the winter of 2008. Regeneration data are collected to the present.

\section{Adjacent catchment - Pond 43}

include an assessment of the effects of timber harvesting on water quality and quantity." This research will assist in the challenge of providing more cost-effective and meaningful assessments of hydrologic impacts than currently exist using various simple models (e.g., WRENNS modelling).

- Similarly, Forest Products Association of Canada (FPAC) companies seeking Forest Stewardship Council (FSC) accreditation to secure national and international markets will use this information about hydrological linkages to maintain the ecologic integrity of harvested ecosystems.

- In collaboration with planners and ecologists from AlPac, FPAC, and staff at Ducks Unlimited Canada (DUC) and Alberta Geologic Survey (AGS), this work will establish a 
hydrologic risk planning process that evaluates the ecological risk and monetary costs of forest harvest on forest succession and water quality and quantity.

- Resulting conceptual and predictive models, and landscape indices can be used to modify surficial geology (AGS) and vegetation map sheets, integrating them with current harvest scheduler and road optimizer programs to produce value-added hydrologic risk assessment layers and effective watershed planning units that include: a) least industry cost and ecological risk road network and spatial harvest scheduler; b) a risk assessment process that will identify hydrologic risk and associated best practices to avoid or mitigate effects from forest harvest as well as road construction; and, c) insight into long-term best management practices to minimize or remediate anthropogenic hydrologic impacts.

- Oil sands companies must reclaim mined areas to sustainable ecosystems that have equivalent capabilities to undisturbed areas.

- The economic impact will be immediate, as reclamation activities are ongoing and operational decisions are already being made about tailings and overburden disposal. The ongoing ability of companies to continue to receive government approval for continued operation is partially contingent upon viable closure plans that include reclamation activities.

- The environmental benefit could also be immediate if research suggests improved means to reconstruct viable landscapes.

- Comparing fluxes of water and $\mathrm{CO}_{2}$ from reclaimed and regenerating stands of varying ages will help industry validate model predictions within the current climate regime and assess the capability of constructed soils to meet current (and future) climatic demands of the ecosystem.

There are numerous articles and summary reports published on these study catchments. Much of the research from the more recent specific Aspen Harvesting study is being written up and is to be submitted for publication.

\section{Acknowledgments}

We acknowledge assistance by Kevin Smith and Julienne Morissette, Ducks Unlimited Canada, and Alberta Geologic Survey. Support provided by Ducks Unlimited Canada Boreal Program, Wetland and Waterfowl Research (IWWR), Syncrude Canada Ltd (\#4410012045), and NSERC-CRD (CRDPJ 238050-00).

\section{References}

Brown, S.M., R.M. Petrone, L. Chasmer, C. Mendoza, M.S. Lazerjan, S. Landhausser and K.J. Devito. 2013. The influence of rooting zone soil moisture on evapotranspiration from above and within a Western Boreal Plain aspen forest. Hydrol. Process. doi: 10.1002/ hyp. 9879.

Carrera-Hernandez, J.J., C.A. Mendoza, K.J. Devito, R.M. Petrone, and B.D. Smerdon. 2011. Effects of aspen harvesting on groundwater recharge and water table dynamics in a subhumid climate. Water Resour. Res. 47: W05542. doi: 10.1029/2010WR009684. Chasmer, L., R.M. Petrone, S.M. Brown, C. Hopkinson, C. Mendoza, J. Diiwu, W. Quinton and K.J. Devito. 2012. Sensitivity of modelled actual evapotranspiration to canopy characteristics within the Western Boreal Plain, Alberta. Remote Sensing and Hydrology, Proceedings of a Symposium at Jackson Hole, Wyoming. September 2010. IAHS Publ. 352: 337-340.

Devito, K., C. Mendoza and C. Qualizza. 2012. Conceptualizing water movement in the Boreal Plains. Implications for watershed reconstruction. Synthesis report prepared for the Canadian Oil Sands Network for Research and Development, Environmental and Reclamation Research Group. 164 p. http://hdl.handle.net/ 10402/era.30206.

Hopkinson, C., L. Chasmer, D. Colville, R.A. Fournier, R.J. Hall, J. Luther, T. Milne, R.M. Petrone and B. St-Onge. 2013. Moving toward consistent ALS monitoring of forest attributes across Canada: A consortium approach. Photogrammetric Engineering \& Remote Sensing 79(2): 159-173.

Petrone, R.M., L. Chasmer, S.M. Brown, K. Giroux, C. Hopkinson, U. Silins, S.M. Landhausser, N. Kljun and K.J. Devito. 2015. Effects of harvesting on $\mathrm{CO}_{2}$ and $\mathrm{H}_{2} \mathrm{O}$ fluxes in an aspen dominated Western Boreal Plain forest. Can. J. For. Res. 45(1): 87-100. doi: 10.1139/cjfr-2014-0253.

Redding T.E. and K.J. Devito. 2010. Mechanism and pathways of lateral flow on aspen-forested, luvisolic soils, Western Boreal Plain, Alberta, Canada. Hydrol. Process. 24: 2995-3010. doi: 10.1002 /hyp.7710.

Sutherland, G., L.E. Chasmer, R.M. Petrone, N. Kljun and K.J. Devito. 2014. Evaluating the use of spatially varying versus bulk average $3 \mathrm{D}$ vegetation structure inputs to modelled evapotranspiration within heterogeneous land cover types. Ecohydrology 7: 1545-1559. doi: 10.1002/eco.1477.

Sutherland, G., L.E. Chasmer, R.M. Petrone, S. Brown, N. Kljun and K.J. Devito. Using high resolution LiDAR data and a flux footprint parameterization to scale evapotranspiration estimates to lower pixel resolutions. (Submitted to Remote Sensing of the Environment) 